\title{
TAILOR WELDED BLANKS
}

\author{
T.Kishore Kumar ${ }^{1}$, K.Jayasimha Reddy ${ }^{2}$ \\ ${ }^{1}$ Assistant Professor, Department of Mechanical Engineering, Dr.K.V.S.R.I.T, A.P, India \\ ${ }^{2}$ Assistant Professor, Department of Mechanical Engineering, Dr.K.V.S.R.I.T, A.P, India
}

\begin{abstract}
A Tailor Welded Blank (TWB) is a weld element where the welding is carried out between metals of two different elements. Tailor welded blanks (TWB's) offer an excellent opportunity to reduce manufacturing costs, decrease vehicle weight and to improve the quality of sheet metal stampings and structural elements. Tailor Welded Blanks (TWBs) offer a means to address all of the concerns by reducing manufacturing costs, decreasing vehicle weight, improving crashworthiness, improving dimensional accuracy of the final part and increasing the corrosion resistance. A TWB is fabricated by welding together two or more sheets of metal of different thicknesses, material grades and/or coatings to produce a single blank, which is subsequently formed. Aluminum TWBs offer additional weight savings and would address the concerns of increased cost and decreased crashworthiness, which normally accompany Aluminum for steel material substitutions. While Aluminum TWBs are currently being implemented for less structural components such as deck lids and hoods, door inners and floor pans are being investigated as possible Aluminum TWB applications for the future. Like tailoring a shirt to suit the need of a person, a TWB is a weld designed to suit the applications. The application varies from strength to light metal. The applications of TWB are variant from the basic automobiles to that of space craft and structural elements.
\end{abstract}

Keywords: Tailor welded blanks ( TWB )

\section{INTRODUCTION}

A tailor welded blank is a weld element where in the welding is carried out between metals of two different elements and of different thicknesses.

During the past two decades, government fuel conservation and safety mandates along with environmental concerns have prompted the American Automotive Industry to design lighter cars for reduced fuel consumption, while improving the overall structure of the vehicles for occupant safety. Corrosion protection was also much improved during this period. These changes added to escalating manufacturing costs at a time when the industry was struggling with a serious threat from global competition.

One area of concern for product engineering, however, has been the higher density of steel versus alternative materials. One of the solutions involves the Tailor Welded Blanks (TWBs), which requires various materials options to be welded together prior to the forming process. Such a concept of combining the available material options into a welded blank enabled engineers to tailor the blanks so that the best properties of the materials were located precisely within the part where they are needed. This process not only reduces the weight of the finished part, but also can be used for part integration, thereby eliminating many reinforcements and stiffeners.

\subsection{Applications}

Tailor welded blanks are used for two purposes:

- Combine several steel options into a welded blank prior to stamping. By combining varying thicknesses, coatings and material grades, the product and manufacturing engineers can tailor the blank to take advantage of the different properties of the steels within the part.

- Integrate and eliminate parts, resulting in savings for tooling, operational costs, and lead time.

Tailor welded blanks are currently used for:

- Door inner panels

- Body side frames

- Underbody frame rails

- Engine compartment rails

- Center pillar inner panels

\subsection{Potential Applications for Tailor Welded Blanks}

Potential product applications are best identified by recognizing the advantages, particularly interms of economics, of tailor welded blanks, which include:

- Part integration and tooling cost reduction

- Improved material yield

- Mass reduction and structural integrity

- $\quad$ Reduced dimensional variation

In assessing the economic effects of part integration, product engineers and designers should assess the following factors:

- Total reduction in parts count, including engineering, design and assembly costs.

- Total reduction in the number of tools, including the costs of designing, building and operating them.

- Cost reduction derived from the selective use of coated steels and different strengths and thickness of steel 


\subsection{Objective}

The main objective of the project is to analyze the weld properties of tailor welded blanks of different materials and different material thicknesses considered under the influence of appropriate weld processes. Tensile Strength, Shear Strength and the Impact Strength of the specimens welded using Tungsten Inert Gas Welding (TIG) and Arc Welding are analyzed. The Micro Graphic Images of the Heat Effected Zones is studies to analyzed the morphology of the specimens. Double lap- V Grove, joint is considered for the specimens of same thickness and fillet weld is considered for the specimens with different thicknesses.

Micro Graphic Images are taken at the heat effected zones of the welded specimens using a Microscope (specifications) before carrying other tests. The images taken for the weld processes considered for the weld processes are compared for grain structure.

Tensile Strength is carried out on the specimens with tensile load applied Parallel to weld and Perpendicular to the weld line for the weld processes considered. Similarly Impact Strength for both the Double Butt TIG welded and Arc welded Stainless Steel and Mild Steel in both parallel and perpendicular directions are determined using Charpy's Impact Test. Further, Shear Strength is determined on the weld specimens with Double Lap Joints.

\subsection{Scope of Study}

The scope of this work includes welding of materials/alloys of two different properties, employing different weld process (compatible to both the materials), evaluating the morphology of the heat effected zone, evaluating material properties of weld zones/materials

The following are considered for the study and analysis of the weld blanks.

\section{Tensile Strength}

Evaluation of Tensile Strength, using UTM (including specifications of the machine and test conditions if required) is one of the primary objectives considered under this work. The work includes,

- Tensile test of weld blanks of different materials for the weld processes considered

- Tensile test of weld blanks of same material but different thickness for the weld processes considered.

- Analysis of weld blanks for tensile failure using FEM analysis.

\section{Shear Strength}

Evaluation of Shear Strength, using UTM (including specifications of the machine and test conditions if required) is one of the primary objectives considered under this work. The work includes,
- Shear Test of weld blanks of different materials for the weld processes considered

- Shear Test of weld blanks of same material but different thickness for the weld processes considered.

- Analysis of weld blanks for Shear failure using FEM analysis.

\section{Impact Strength}

Evaluation of Shear Strength, using Charpy's Impact Test (including specifications of the machine and test conditions if required) is one of the primary objectives considered under this work. The work includes,

- Impact Test of weld blanks of different materials for the weld processes considered

- Analysis of weld blanks for Impact failure using FEM analysis.

\section{Micro Graphic Images}

Evaluation of Grain Sizes using a Micro Scope near the heat effected zone is one of the primary objective considered under this work.

\section{EXPERIMENTAL SETUP}

\subsection{Tungsten Inert Gas Welding}

Gas tungsten arc welding (GTAW), also known as tungsten inert gas (TIG)welding, is an arc welding process that uses a non-consumable tungsten electrode to produce the weld. The weld area is protected from atmospheric contamination by a shielding gas (usually an inert gas such as argon), and afiller metal is normally used, though some welds, known as autogenous welds, do not require it. A constant-current welding power supply produces energy which is conducted across the arc through a column of highly ionized gas and metal vapors known as a plasma.

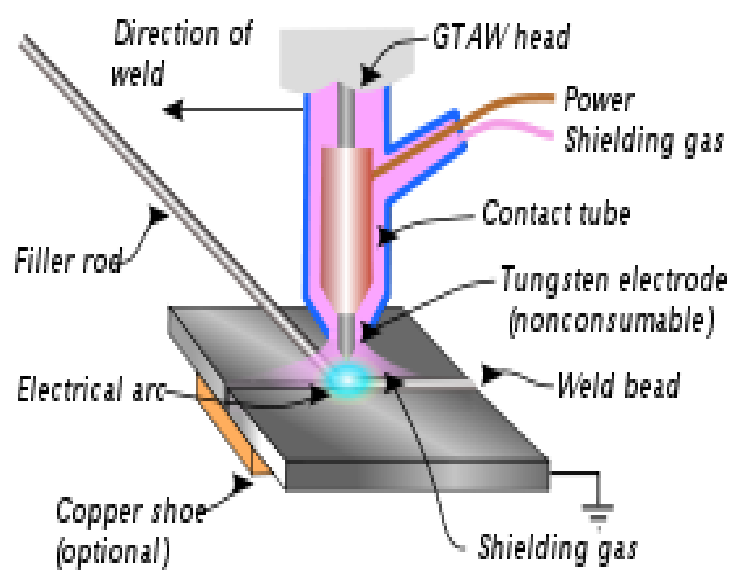

Fig 2.2 GTAW weld area 


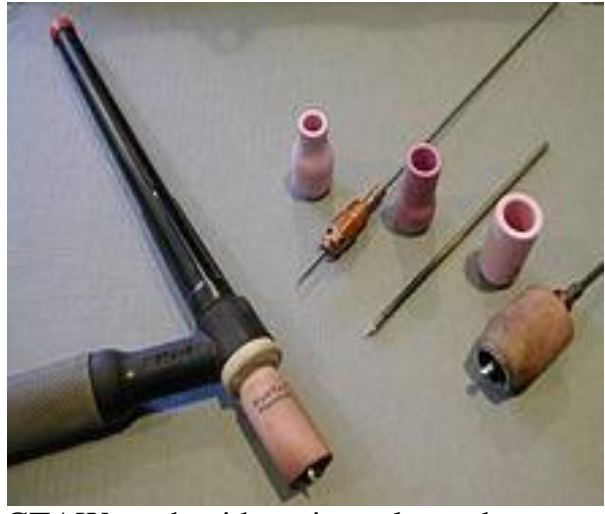

Fig 2.3 GTAW torch with various electrodes, cups, collets and gas diffusers

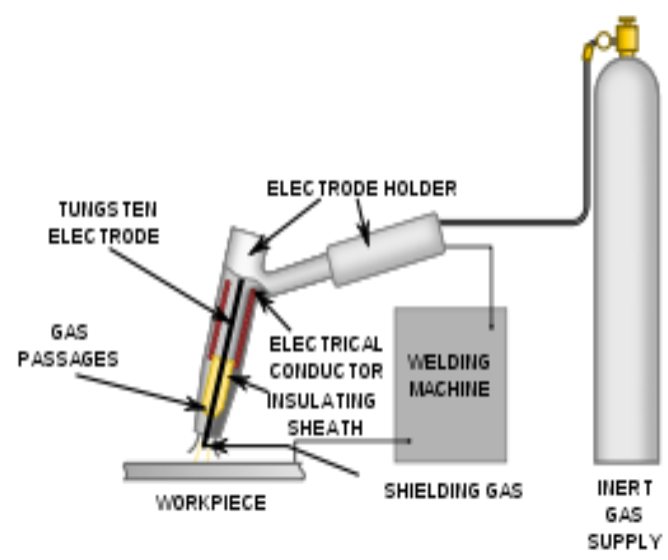

Fig 2.4 GTAW system setup

\subsection{Arc Welding}

Arc welding is a type of welding that uses a welding power supply to create an electric arcbetween an electrode and the base material to melt the metals at the welding point. They can use either direct (DC) or alternating (AC) current, and consumable or non-consumableelectrodes. The welding region is usually protected by some type of shielding gas, vapor, and/or slag.

\subsection{Charpy's Impact Test}

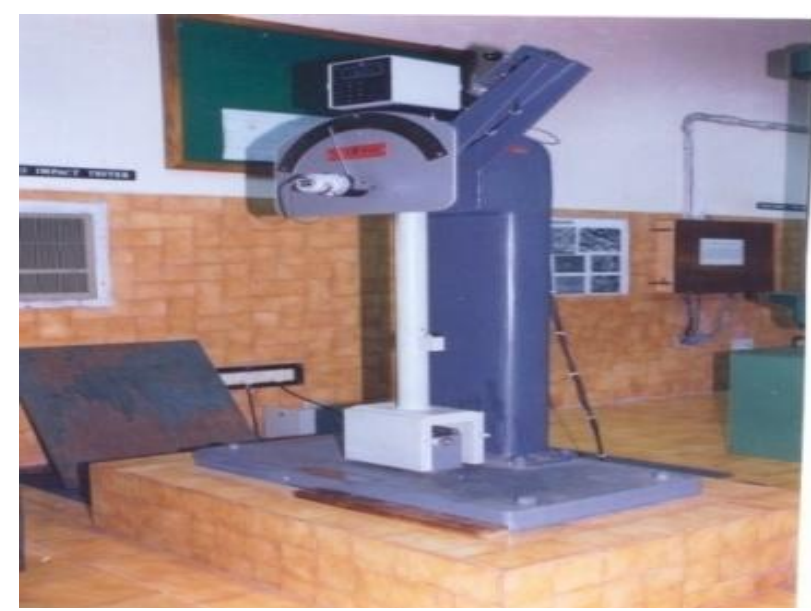

Fig.2.5 Impact Test Equipment
The Charpy's Impact Test, also known as the Charpy's Vnotch Test, is a standardized high strain-rate test which determines the amount of energy absorbed by a material during fracture. This absorbed energy is a measure of a given material's toughness and acts as a tool to study temperature-dependent ductile-brittle transition. It is widely applied in industry, since it is easy to prepare and conduct and results can be obtained quickly and cheaply. A major disadvantage is that all results are only comparative. The test was developed in 1905 by French scientist Georges Charpy. It was pivotal in understanding the fracture problems of ships during World War II. Today it is used in many industries for testing materials used in the construction of pressure vessels and bridges and to determine how storms will affect materials used in them.

\subsection{Universal Testing Mahine}

A Universal Testing Machine is also called as Universal Tester or Materials Testing Machine or Materials Test Frame is used to test the Tensile Stress and Compressive Stress of the materials. It is named after the fact that it can perform many standard tensile and compression tests on materials, components and structures

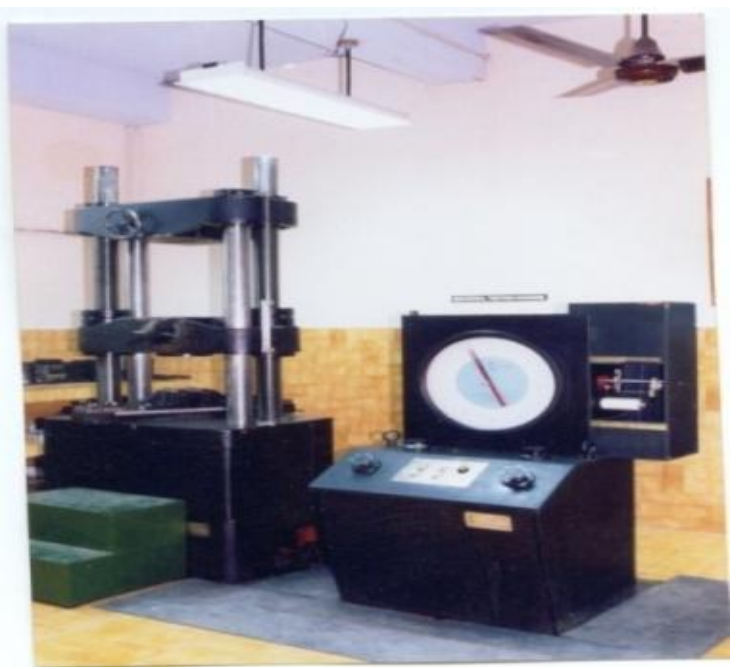

Fig 2.6 UTM Equipment

\section{EXPERIMENTAL PROCEDURE}

In our study we considered two materials namely Stainless Steel and Mild Steel of Flat Plates in cross-section, having same and different thicknesses, which are welded using two welding methods. which are Tungsten Inert Gas(TIG) Welding and Arc Welding. By using these welding methods the specimens are welding for performing Tensile Test, Shear Test and Impact Stress.

Firstly, for Tensile Stress the specimens having same thicknesses are welding by both the above mentioned welding methods with double $\mathrm{V}$-joint at the weld area and the welded specimen is placed in the Universal Testing Machine for test and the reading are noted, the Tensile Stess is calculated. Later the specimens having different thickness are welded and the same procedure is performed and tensile stress Parallel and Perpendicular to weld is determined. 
For determining the Shear Stress, the specimens having same thicknesses and different thicknesses are welded using the two mentioned welding methods with a double Lap joint at the weld area and is placed in UTM for test. Then. The load is applied and the Shear Stress is calculated.

For determining the Impact Strength, the specimens having the same thickness is welded using TIG and Arc welding processes and a Notch is placed at the weld area before performing the test over it. Later for determining the Impact Strength, Charpy's Impact Test is used. In this, the test piece is placed in the equipment and a pendulum is released over the work piece, through which the Energy absorbed will be noted through which the Imoact Strength is calculated.

Finally, the grain sizes are taken near the weld area in both the welding procedures by means of a Micrograph and are compared among them and with the mother pieces.

Results of the Tensile Strength, Shear Strength, Impact Strength and Micrographic Images of the grains near the weld zone are mentioned in the next chapter.

\section{RESULTS AND DISCUSSION}

\subsection{Double Arc Butt Joint}

A specimen corresponding to the combination ofStainless steel and mild steel specimens of width $50 \mathrm{~mm}$ having thickness of $5 \mathrm{~mm}$ each and length of $180 \mathrm{~mm}$ (for tensile strength) and length of $10 \mathrm{~mm}$ (for impact strength) each are welded by arc welding with double weld joint. This specimen is tested for tensile and impact strengths under UTM and Charpy's Impact Test and the results are as follows:

\subsubsection{Charpy's Impact Test}

\section{i) Parallel to Weld Specimen}

1) Area of the specimen under the test $=60 \mathrm{~mm}^{2}$

2) Energy absorbed by the specimen $=92 \mathrm{~J}$

3) Impact strength of the specimen $=1.533 \mathrm{~J} / \mathrm{mm}^{2}$

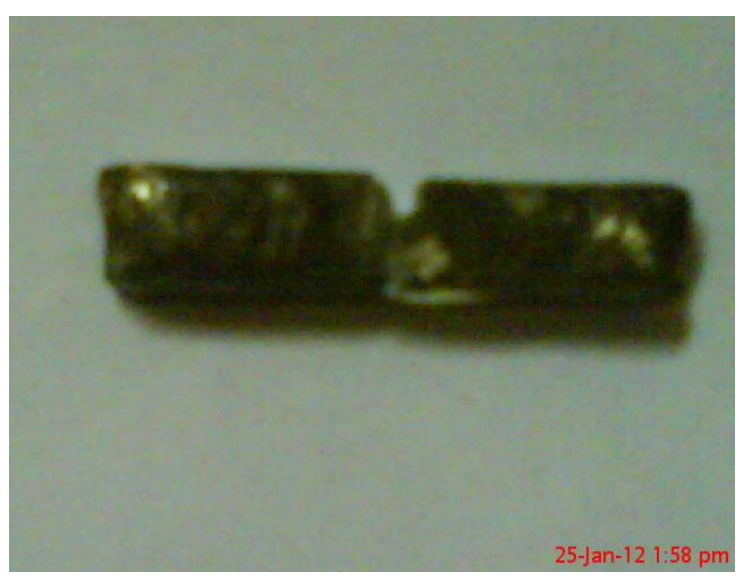

Fig 4.1 Specimen Before test

ii) Perpendicular to Weld Specimen
1) Area of the specimen under the test $=65.1868 \mathrm{~mm}^{2}$

2) Energy absorbed by the specimen $=202 \mathrm{~J}$

3) Impact strength of the specimen $=3.0988 \mathrm{~J} / \mathrm{mm}^{2}$
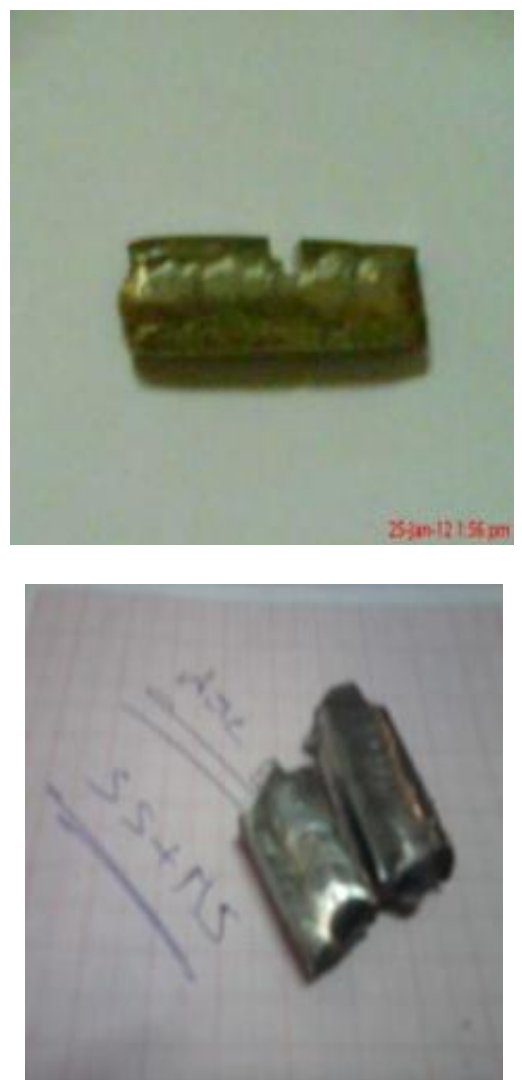

Fig 4.2 Specimen Before Test Specimen After Test

\subsubsection{Tensile strength}

The specimens with above mentioned dimensionsare loaded in universal testing machine and tensile strength is calculated as fallows when the weld is perpendicular to the application of load

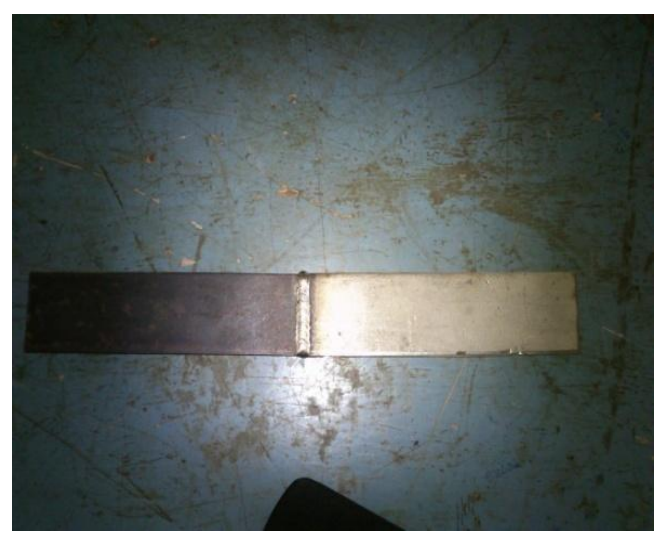




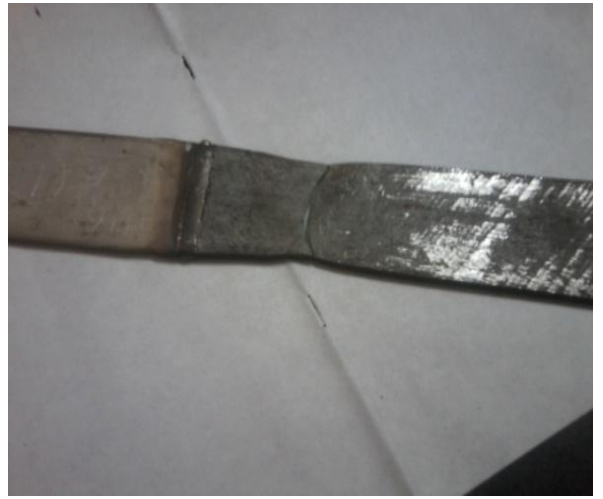

Fig 4.3 Specimen Before Test Specimen After Test

1) Initial width of the specimen(w) $=50 \mathrm{~mm}$

2) Neck width of the $\operatorname{specimen}\left(\mathrm{w}^{\prime}\right)=45 \mathrm{~mm}$

3) Initial thickness of the specimen $(\mathrm{t})=6 \mathrm{~mm}$

4) Neck thickness of the specimen $\left(\mathrm{t}^{\prime}\right)=5 \mathrm{~mm}$

5) Initial length of the specimen $(\mathrm{l})=359 \mathrm{~mm}$

6) Final length of the specimen $\left(\mathrm{l}^{\prime}\right)=396 \mathrm{~mm}$

7) Area of the specimen $(\mathrm{A})=300 \mathrm{sq} \cdot \mathrm{mm}$

8) Neck area of the specimen $\left(\mathrm{A}^{\prime}\right)=225$ sq.mm

9) Elastic strength of the $\operatorname{specimen}\left(\mathrm{w}_{\mathrm{e}}\right)=3678.75 \mathrm{~N}$

10) Breaking strength of the specimen $\left(\mathrm{w}_{\mathrm{b}}\right)=129982.5 \mathrm{~N}$

11) Ultimate strength of the $\operatorname{specimen}\left(\mathrm{w}_{\mathrm{ult}}\right)=147150 \mathrm{~N}$

12) Elastic limit stress of the $\operatorname{specimen}\left(\mathrm{w}_{\mathrm{e}} / \mathrm{A}\right)=12.26$ $\mathrm{N} / \mathrm{sq} . \mathrm{mm}$

13) Nominal breaking stress of the $\operatorname{specimen}\left(\mathrm{w}_{\mathrm{b}} / \mathrm{A}\right)=$ 433.278727 N/sq.mm

14) Actual breaking stress $\left(\mathrm{w}_{\mathrm{b}} / \mathrm{A}^{\prime}\right)=577.7109 \mathrm{~N} / \mathrm{mm}^{2}$

15) Percentage of elongation $=10.33 \%$

16) Percentage reduction in Area $=25 \%$

17) Percentage reduction in width $=10 \%$

18) Percentage reduction in thickness $=16.667 \%$

\subsection{Double Butt Tig Joint}

A specimen corresponding to the combination ofStainless steel and mild steel specimens of width $50 \mathrm{~mm}$ having thickness of $5 \mathrm{~mm}$ and length of $180 \mathrm{~mm}$ (for tensile strength) and length of $10 \mathrm{~mm}$ (for impact strength) each are welded by tig welding with double weld joint. This specimen is tested for tensile and impact strengths under UTM and Charpy's Impact Test and the results are as follows:

\subsubsection{Charpy's Impact Test}

\section{i) Parallel to Weld Specimen}

1) Area of the specimen under the test $=43.1949 \mathrm{~mm}^{2}$

2) Energy absorbed by the specimen $=50 \mathrm{~J}$

3) Impact strength of the specimen $=1.1575 \mathrm{~J} / \mathrm{mm}^{2}$
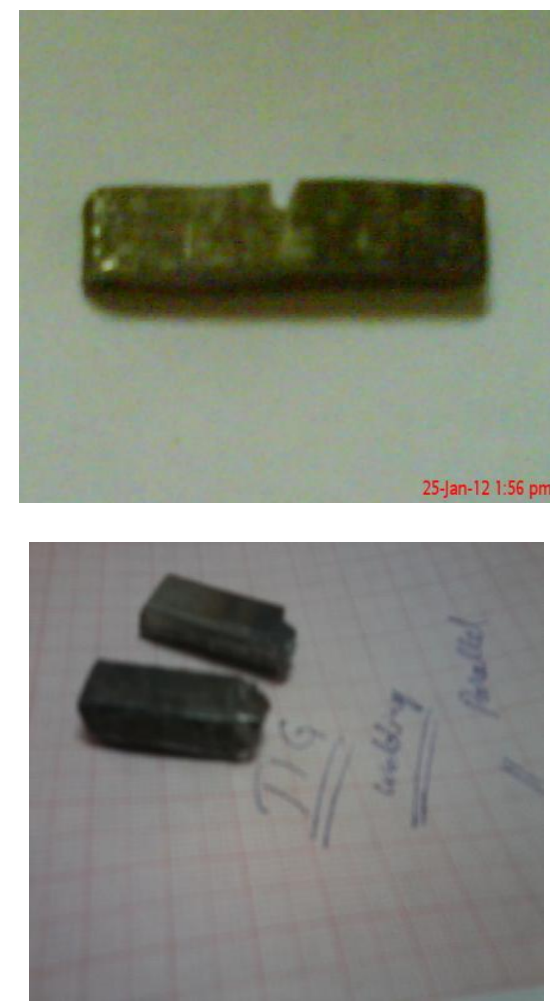

Fig 4.4 Specimen Before Test Specimen After Test

\section{ii) Perpendicular to Weld Specimen}

1) Area of the specimen under the test $=43.4767 \mathrm{~mm}^{2}$

2) Energy absorbed by the specimen $=46 \mathrm{~J}$

3) Impact strength of the specimen $=1.05804 \mathrm{~J} / \mathrm{mm}^{2}$
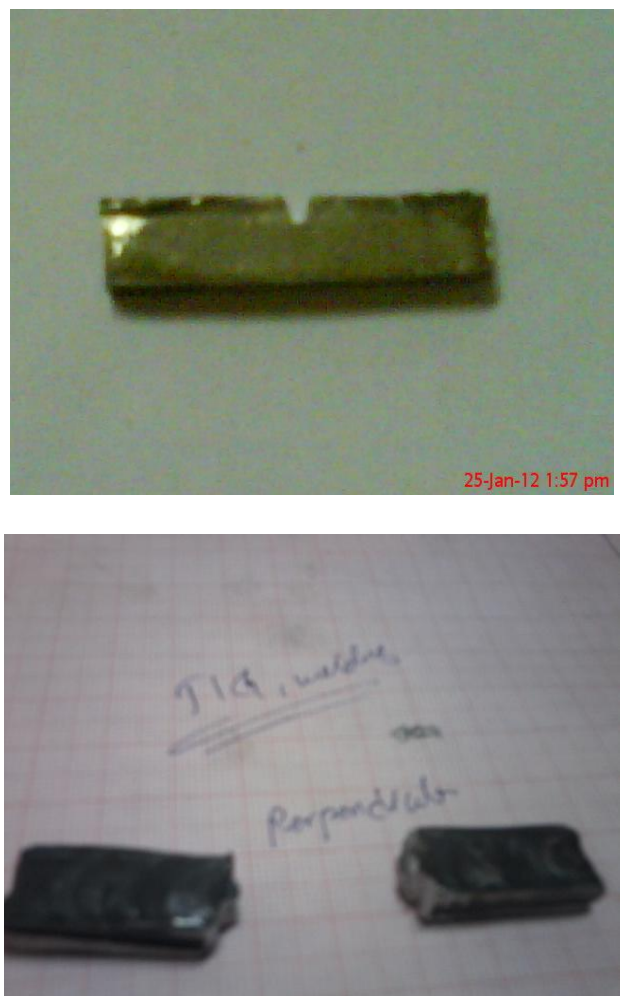

Fig 4.5 Specimen Before Test Specimen After Test 


\subsubsection{Tensile Strength}

The specimens with above mentioned dimensionsare loaded in universal testing machine and tensile strength is calculated as fallows when the weld is perpendicular to the application of load.
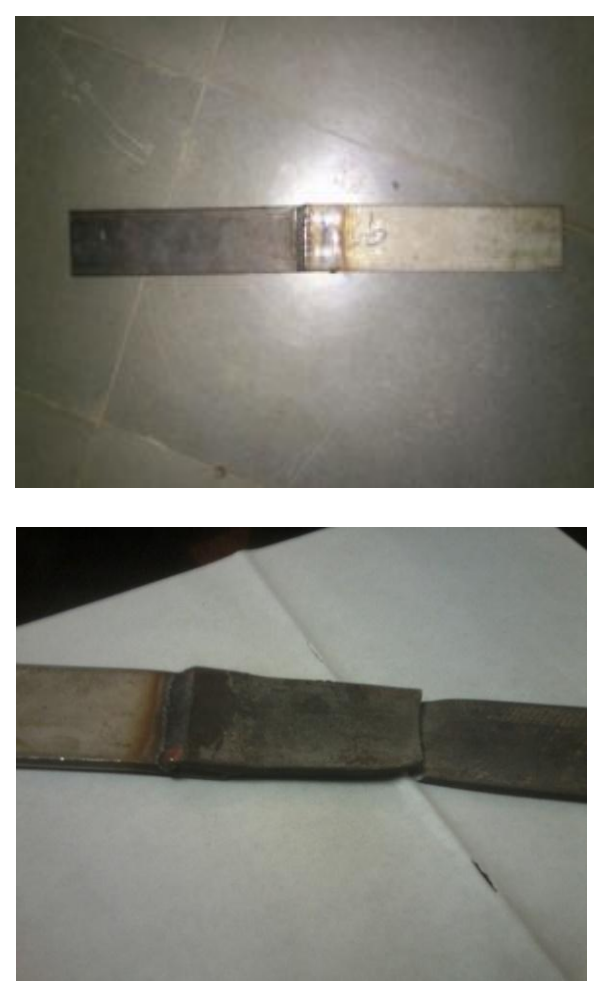

Fig 4.6 Specimen before Test Specimen After Test

1) Initial width of the specimen(w) $=50 \mathrm{~mm}$

2) Neck width of the $\operatorname{specimen}\left(\mathrm{w}^{\prime}\right)=41 \mathrm{~mm}$

3) Initial thickness of the specimen $(\mathrm{t})=6 \mathrm{~mm}$

4) Neck thickness of the specimen $\left(\mathrm{t}^{\prime}\right)=5 \mathrm{~mm}$

5) Initial length of the specimen $(\mathrm{l})=359 \mathrm{~mm}$

6) Final length of the specimen $\left(\mathrm{l}^{\prime}\right)=392 \mathrm{~mm}$

7) Area of the specimen $(\mathrm{A})=300 \mathrm{~mm}^{2}$

8) Neck area of the $\operatorname{specimen}\left(\mathrm{A}^{\prime}\right)=205 \mathrm{~mm}^{2}$

9) Elastic strength of the specimen $\left(W_{\ell}\right)=3678.75 \mathrm{~N}$

10) Breaking strength of the specimen $\left(\mathrm{w}_{\mathrm{b}}\right)=145188 \mathrm{~N}$

11) Ultimate strength of the specimen $\left(\mathrm{w}_{\mathrm{ult}}\right)=128511 \mathrm{~N}$

12) Elastic limit stress of the $\operatorname{specimen}\left(\mathrm{w}_{\mathrm{e}} / \mathrm{A}\right)=12.2625 \mathrm{~N} /$ $\mathrm{mm}^{2}$

13) Nominal breaking stress of the $\operatorname{specimen}\left(\mathrm{w}_{\mathrm{b}} / \mathrm{A}\right)=$ $427.716 \mathrm{~N} / \mathrm{mm}^{2}$

14) Actual breaking stress $\left(\mathrm{w}_{\mathrm{b}} / \mathrm{A}^{\prime}\right)=626.859 \mathrm{~N} / \mathrm{mm}^{2}$

15) Percentage of elongation $=9.19 \%$

16) Percentage reduction in Area $=18 \%$

17) Percentage reduction in width $=31.6 \%$

18) Percentage reduction in thickness $=16.67 \%$

\subsection{Double Lap Arc Joint}

A specimen corresponding to the combination ofStainless steel and mild steel specimens of width $50 \mathrm{~mm}$ having thickness of $5 \mathrm{~mm}$ and length of $210 \mathrm{~mm}$ (for tensile strength) each are welded by arc welding with double weld joint. This specimen is tested for tensile strengths under UTM and the results are as follows:

\subsubsection{Tensile Strength}

The specimens with above mentioned dimensions are loaded in universal testing machine and tensile strength is calculated as fallows when the weld is perpendicular to the application of load.
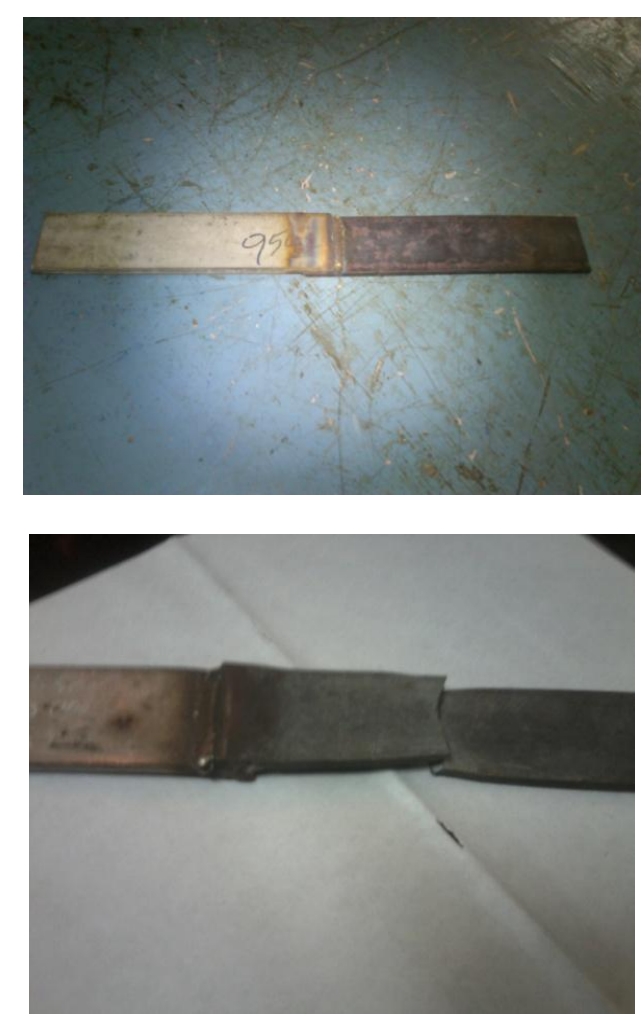

Fig 4.7 Specimen Before Test Specimen After Test

1) Initial width of the $\operatorname{specimen}(\mathrm{w})=50 \mathrm{~mm}$

2) Neck width of the $\operatorname{specimen}\left(\mathrm{w}^{\prime}\right)=45 \mathrm{~mm}$

3) Initial thickness of the specimen $(\mathrm{t})=6 \mathrm{~mm}$

4) Neck thickness of the specimen $\left(\mathrm{t}^{\prime}\right)=5 \mathrm{~mm}$

5) Initial length of the specimen $(1)=422 \mathrm{~mm}$

6) Final length of the specimen $\left(\mathrm{l}^{\prime}\right)=459 \mathrm{~mm}$

7) Area of the $\operatorname{specimen}(\mathrm{A})=300$ sq. $\mathrm{mm}$

8) Neck area of the $\operatorname{specimen}\left(\mathrm{A}^{\prime}\right)=225 \mathrm{sq} . \mathrm{mm}$

9) Elastic strength of the $\operatorname{specimen}\left(\mathrm{w}_{\mathrm{e}}\right)=3678.75 \mathrm{~N}$

10) Breaking strength of the specimen $\left(\mathrm{w}_{\mathrm{b}}\right)=142245 \mathrm{~N}$

11) Ultimate strength of the specimen $\left(\mathrm{w}_{\mathrm{ult}}\right)=127530 \mathrm{~N}$

12) Elastic limit stress of the $\operatorname{specimen}\left(\mathrm{w}_{\mathrm{e}} / \mathrm{A}\right)=12.2625$ $\mathrm{N} / \mathrm{sq} \cdot \mathrm{mm}$

13) Nominal breaking stress of the $\operatorname{specimen}\left(\mathrm{w}_{\mathrm{b}} / \mathrm{A}\right)=$ $425.0673 \mathrm{~N} / \mathrm{sq} . \mathrm{mm}$

14) Actual breaking stress $\left({ }^{W_{b} / \mathrm{A}^{\prime}}\right)=566.8218 \mathrm{~N} / \mathrm{sq} . \mathrm{mm}$

15) Percentage of elongation $=8.76 \%$

16) Percentage reduction in Area $=10 \%$

17) Percentage reduction in width $=25 \%$

18) Percentage reduction in thickness $=16.66 \%$ 


\subsection{Double Lap TIG Joint}

A specimen corresponding to the combination ofStainless steel and mild steel specimens of width $50 \mathrm{~mm}$ having thickness of $5 \mathrm{~mm}$ and length of $210 \mathrm{~mm}$ (for tensile strength) each are welded by tig welding with double weld joint. This specimen is tested for tensile strengths under UTM and the results are as follows:

\subsubsection{Tensile Strength}

The specimens with above mentioned dimensions are loaded in universal testing machine and tensile strength is calculated as fallows when the weld is perpendicular to the application of load.
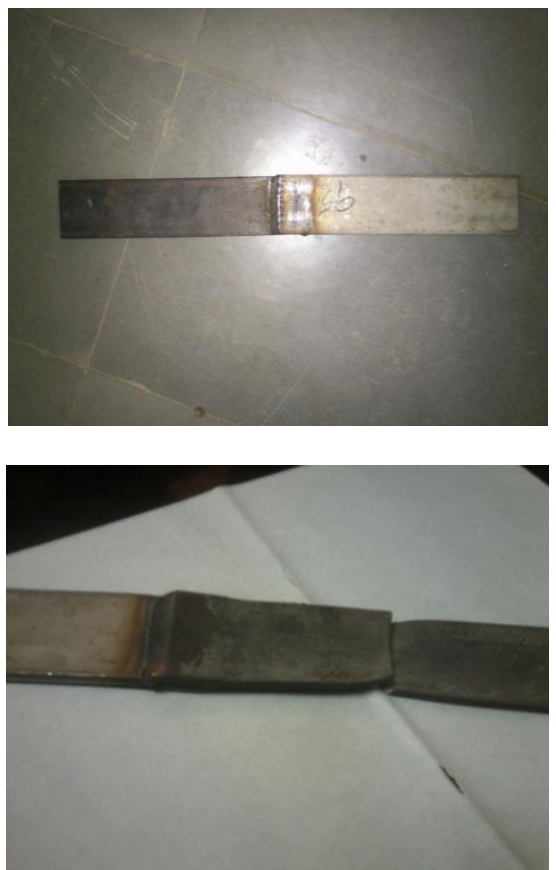

Fig 4.8 Specimen Before Test Specimen After Test

1) Initial width of the $\operatorname{specimen}(\mathrm{w})=50 \mathrm{~mm}$

2) Neck width of the $\operatorname{specimen}\left(w^{\prime}\right)=40 \mathrm{~mm}$

3) Initial thickness of the specimen $(\mathrm{t})=6 \mathrm{~mm}$

4) Neck thickness of the specimen $\left(t^{\prime}\right)=5 \mathrm{~mm}$

5) Initial length of the specimen(l)=419 $\mathrm{mm}$

6) Final length of the specimen $\left(\mathrm{l}^{\prime}\right)=457 \mathrm{~mm}$

7) Area of the specimen $(A)=300 \mathrm{sq} . \mathrm{mm}$

8) Neck area of the specimen $\left(\mathrm{A}^{\prime}\right)=200 \mathrm{sq} \cdot \mathrm{mm}$

9) Elastic strength of the $\operatorname{specimen}\left(\mathrm{w}_{\mathrm{e}}\right)=3678.75 \mathrm{~N}$

10) Breaking strength of the specimen $\left(\mathrm{w}_{\mathrm{b}}\right)=143716.5 \mathrm{~N}$

11) Ultimate strength of the $\operatorname{specimen}\left(\mathrm{w}_{\mathrm{ult}}\right)=126058.5 \mathrm{~N}$

12) Elastic limit stress of the $\operatorname{specimen}\left(\mathrm{w}_{\mathrm{e}} / \mathrm{A}\right)=12.2625$ $\mathrm{N} / \mathrm{sq} . \mathrm{mm}$

13) Nominal breaking stress of the $\operatorname{specimen}\left(\mathrm{w}_{\mathrm{b}} / \mathrm{A}\right)=$ $420.1623 \mathrm{~N} / \mathrm{sq} . \mathrm{mm}$

14) Actual breaking stress $\left(W_{b} / \mathrm{A}^{\prime}\right)=630.2925 \mathrm{~N} / \mathrm{sq} . \mathrm{m}$

15) Percentage of elongation $=9.06 \%$

16) Percentage reduction in Area $=20 \%$

17) Percentage reduction in width $=33.33 \%$

18) Percentage reduction in thickness $=16.67 \%$

\subsection{Double Arc Butt Joint(with different Thickness}

\section{Perpendicular to Weld)}

A specimen corresponding to the combination ofStainless steel and mild steel specimens of width $48 \mathrm{~mm}, 50 \mathrm{~mm}$ having thicknesses of $3 \mathrm{~mm}, 5 \mathrm{~mm}$ and length of $213 \mathrm{~mm}$ respectively each are welded by arc welding with double weld joint. This specimen is tested for tensile strengths under UTM and the results are as follows:

\subsubsection{Tensile Strength}

The specimens with above mentioned dimensions are loaded in universal testing machine and tensile strength is calculated as fallows when the weld is perpendicular to the application of load.
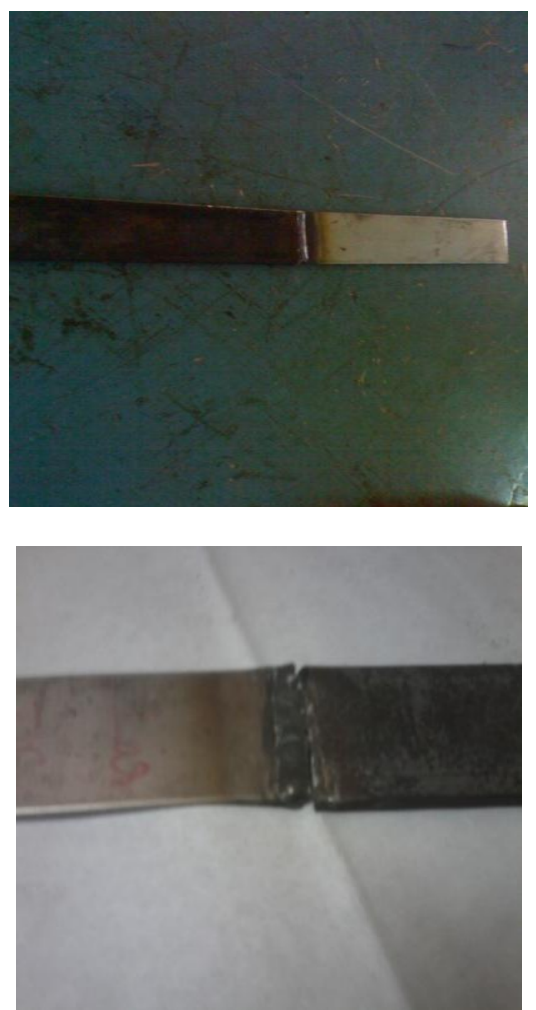

Fig 4.9 Specimen Before Test Specimen After Test

1) Initial width of the $\operatorname{specimen}(\mathrm{w})=48 \mathrm{~mm}$

2) Neck width of the $\operatorname{specimen}\left(w^{\prime}\right)=48.7 \mathrm{~mm}$

3) Initial thickness of the specimen $(\mathrm{t})=3 \mathrm{~mm}$

4) Neck thickness of the specimen $\left(\mathrm{t}^{\prime}\right)=5 \mathrm{~mm}$

5) Initial length of the specimen $(1)=427 \mathrm{~mm}$

6) Final length of the specimen $\left(\mathrm{l}^{\prime}\right)=464 \mathrm{~mm}$

7) Area of the specimen $(\mathrm{A})=144 \mathrm{~mm}^{2}$

8) Neck area of the $\operatorname{specimen}\left(\mathrm{A}^{\prime}\right)=146.1 \mathrm{~mm}^{2}$

9) Elastic strength of the specimen $\left(W_{Q}\right)=3433.5 \mathrm{~N}$

10) Breaking strength of the specimen $\left(\mathrm{w}_{\mathrm{b}}\right)=108891 \mathrm{~N}$

11) Ultimate strength of the specimen $\left(\mathrm{w}_{\mathrm{ult}}\right)=108891 \mathrm{~N}$

12) Elastic limit stress of the $\operatorname{specimen}\left(\mathrm{w}_{\mathrm{e}} / \mathrm{A}\right)=23.8383$ $\mathrm{N} / \mathrm{sq} . \mathrm{mm}$

13) Nominal breaking stress of the $\operatorname{specimen}\left(W_{b} / \mathrm{A}\right)=$ $756.1548 \mathrm{~N} / \mathrm{mm}^{2}$ 
14) Actual breaking stress $\left(\mathrm{w}_{\mathrm{b}} / \mathrm{A}^{\prime}\right)=745.3638 \mathrm{~N} / \mathrm{mm}^{2}$

15) Percentage of elongation $=8.66 \%$

16) Percentage reduction in Area $=1.46 \%$

17) Percentage reduction in width $=66.67 \%$

18) Percentage reduction in thickness $=1.458 \%$

\subsection{Double Arc Butt Joint (with different Thickness}

\section{Parallel to Weld)}

A specimen corresponding to the combination ofStainless steel and mild steel specimens of width $30 \mathrm{~mm}$ each having thickness of $3 \mathrm{~mm}, 5 \mathrm{~mm}$ and length of $175 \mathrm{~mm}$ respectively each are welded by arc welding with double weld joint. This specimen is tested for tensile strengths under UTM and the results are as follows:

\subsubsection{Tensile Strength}

The specimens with above mentioned dimensions are loaded in universal testing machine and tensile strength is calculated as fallows when the weld is parallel to the application of load.
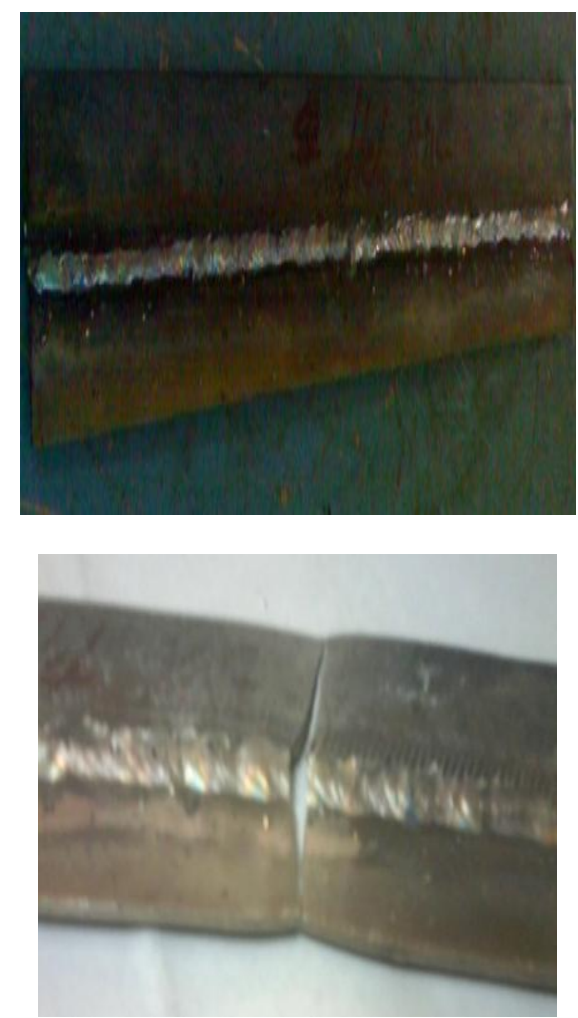

Fig 4.10 Specimen Before Test Specimen After Test

1) Initial width of the specimen $(w)=62 \mathrm{~mm}$

2) Neck width of the $\operatorname{specimen}\left(w^{\prime}\right)=56 \mathrm{~mm}$

3) Initial thickness of the specimen $(\mathrm{t})=3 \mathrm{~mm}$

4) Neck thickness of the specimen $\left(t^{\prime}\right)=2.5 \mathrm{~mm}$

5) Initial length of the specimen $(\mathrm{l})=350 \mathrm{~mm}$

6) Final length of the specimen $\left(\mathrm{l}^{\prime}\right)=371 \mathrm{~mm}$

7) Area of the specimen $(A)=186 \mathrm{sq} . \mathrm{mm}$

8) Neck area of the $\operatorname{specimen}\left(\mathrm{A}^{\prime}\right)=140$ sq.mm

9) Elastic strength of the $\operatorname{specimen}\left(W_{e}\right)=3433.5 \mathrm{~N}$

10) Breaking strength of the $\operatorname{specimen}\left(\mathrm{w}_{\mathrm{b}}\right)=130473 \mathrm{~N}$
11) Ultimate strength of the specimen $\left(\mathrm{w}_{\mathrm{ult}}\right)=130473 \mathrm{~N}$

12) Elastic limit stress of the $\operatorname{specimen}\left(\mathrm{w}_{\mathrm{e}} / \mathrm{A}\right)=18.46$ $\mathrm{N} / \mathrm{sq} . \mathrm{mm}$

13) Nominal breaking stress of the $\operatorname{specimen}\left(\mathrm{w}_{\mathrm{b}} / \mathrm{A}\right)=$ $701.46405 \mathrm{~N} / \mathrm{sq} . \mathrm{mm}$

14) Actual breaking stress $\left(W_{b} / \mathrm{A}^{\prime}\right)=872.1 \mathrm{~N} / \mathrm{sq} \cdot \mathrm{mm}$

15) Percentage of elongation $=6 \%$

16) Percentage reduction in Area $=16.67 \%$

17) Percentage reduction in width $=9.67 \%$

18) Percentage reduction in thickness $=24.73 \%$

\subsection{Double Butt TIG Joint (with different}

\section{Thickness Perpendicular Weld)}

A specimen corresponding to the combination ofStainless steel and mild steel specimens of width $48 \mathrm{~mm}, 50 \mathrm{~mm}$ having thickness of $3 \mathrm{~mm}, 5 \mathrm{~mm}$ and length of $212 \mathrm{~mm}, 212$ $\mathrm{mm}$ respectively each are welded by tig welding with double weld joint. This specimen is tested for tensile strengths under UTM and the results are as follows:

\subsubsection{Tensile Strength}

The specimens with above mentioned dimensions are loaded in universal testing machine and tensile strength is calculated as fallows when the weld is perpendicular to the application of load.
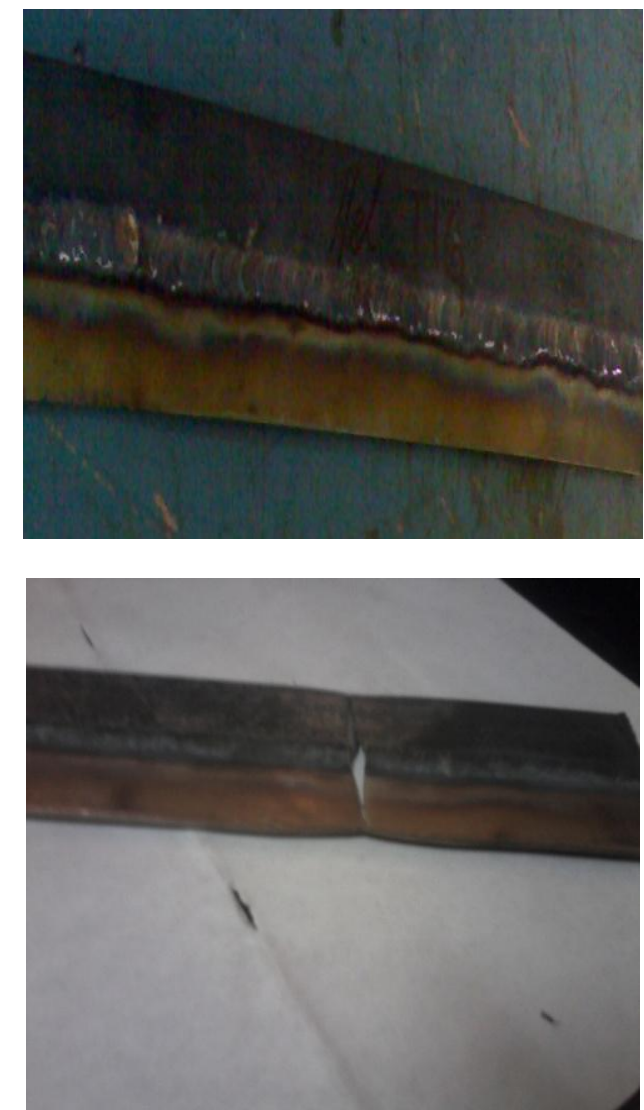

Fig 4.11 Specimen Before Test Specimen After Test

1) Initial width of the specimen $(\mathrm{w})=48 \mathrm{~mm}$

2) Neck width of the specimen $\left(\mathrm{w}^{\prime}\right)=49 \mathrm{~mm}$

3) Initial thickness of the specimen $(\mathrm{t})=3 \mathrm{~mm}$ 
4) Neck thickness of the specimen $\left(\mathrm{t}^{\prime}\right)=5.5 \mathrm{~mm}$

5) Initial length of the $\operatorname{specimen}(\mathrm{l})=425 \mathrm{~mm}$

6) Final length of the specimen $\left(\mathrm{l}^{\prime}\right)=461 \mathrm{~mm}$

7) Area of the specimen $(A)=144$ sq.mm

8) Neck area of the $\operatorname{specimen}\left(\mathrm{A}^{\prime}\right)=269.5$ sq.mm

9) Elastic strength of the $\operatorname{specimen}\left(W_{Q}\right)=3433.5 \mathrm{~N}$

10) Breaking strength of the specimen $\left(\mathrm{w}_{\mathrm{b}}\right)=107910 \mathrm{~N}$

11) Ultimate strength of the specimen $\left(\mathrm{w}_{\mathrm{ult}}\right)=98100 \mathrm{~N}$

12) Elastic limit stress of the $\operatorname{specimen}\left(\mathrm{w}_{\mathrm{e}} / \mathrm{A}\right)=$ 23.844N/sq.mm

13) Nominal breaking stress of the $\operatorname{specimen}\left(\mathrm{w}_{\mathrm{b}} / \mathrm{A}\right)=$ $6810206 \mathrm{~N} / \mathrm{sq} . \mathrm{mm}$

14) Actual breaking stress $\left(\mathrm{w}_{\mathrm{b}} / \mathrm{A}^{\prime}\right)=364.0491 \mathrm{~N} / \mathrm{sq} . \mathrm{mm}$

15) Percentage of elongation $=8.47 \%$

16) Percentage reduction in Area $=83.33 \%$

17) Percentage reduction in width $=2.08 \%$

18) Percentage reduction in thickness $=87.15 \%$

\subsection{Double Butt TIG Joint (with different}

\section{Thickness Parallel to Weld)}

A specimen corresponding to the combination ofStainless steel and mild steel specimens of width $32 \mathrm{~mm}$ each, $50 \mathrm{~mm}$ having thickness of $3 \mathrm{~mm}, 5 \mathrm{~mm}$ and length of $175 \mathrm{~mm}, 175$ $\mathrm{mm}$ respectively each are welded by a tig welding with double weld joint. This specimen is tested for tensile strengths under UTM and the results are as follows:

\subsubsection{Tensile Strength}

The specimens with above mentioned dimensions are loaded in universal testing machine and tensile strength is calculated as fallows when the weld is parallel to the application of load.
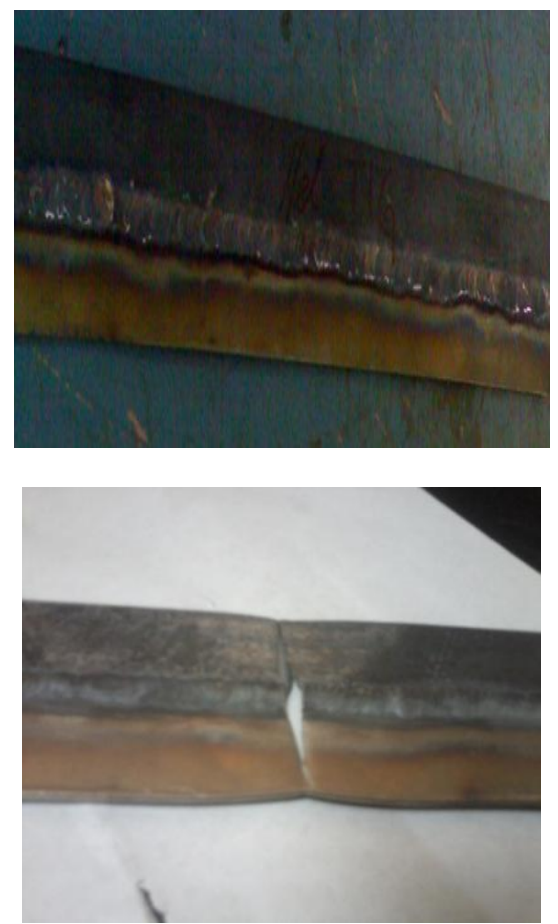

Fig 4.12 Specimen Before Test Specimen After Test

1) Initial width of the $\operatorname{specimen}(\mathrm{w})=65 \mathrm{~mm}$
2) Neck width of the specimen $\left(\mathrm{w}^{\prime}\right)=56 \mathrm{~mm}$

3) Initial thickness of the specimen $(\mathrm{t})=3 \mathrm{~mm}$

4) Neck thickness of the specimen $\left(\mathrm{t}^{\prime}\right)=2.16 \mathrm{~mm}$

5) Initial length of the specimen $(\mathrm{l})=351 \mathrm{~mm}$

6) Final length of the specimen $\left(\mathrm{l}^{\prime}\right)=362 \mathrm{~mm}$

7) Area of the specimen(A) $=195$ sq.mm

8) Neck area of the $\operatorname{specimen}\left(\mathrm{A}^{\prime}\right)=120.96 \mathrm{sq} . \mathrm{mm}$

9) Elastic strength of the $\operatorname{specimen}\left(W_{e}\right)=3433.5 \mathrm{~N}$

10) Breaking strength of the $\operatorname{specimen}\left(\mathrm{w}_{\mathrm{b}}\right)=123115.5 \mathrm{~N}$

11) Ultimate strength of the specimen $\left(\mathrm{w}_{\mathrm{ult}}\right)=123115.5 \mathrm{~N}$

12) Elastic limit stress of the $\operatorname{specimen}\left(\mathrm{w}_{\mathrm{e}} / \mathrm{A}\right)=$ $17.60 \mathrm{~N} / \mathrm{sq} . \mathrm{mm}$

13) Nominal breaking stress of the $\operatorname{specimen}\left(W_{b} / \mathrm{A}\right)=$ $631.3716 \mathrm{~N} / \mathrm{sq} . \mathrm{mm}$

14) Actual breaking stress $\left(\mathrm{w}_{\mathrm{b}} / \mathrm{A}^{\prime}\right)=1017.787 \mathrm{~N} / \mathrm{sq} . \mathrm{mm}$

15) Percentage of elongation $=3.139 \%$

16) Percentage reduction in Area $=28 \%$

17) Percentage reduction in width $=13.85 \%$

18) Percentage reduction in thickness $=37.97 \%$

\subsection{Impact Strength of Mild Steel}

Mild Steel specimen having the dimensions of $5 \mathrm{~mm}$ thickness, $10 \mathrm{~mm}$ width and $50 \mathrm{~mm}$ length is tested fot Impact Strength in the Charpy's Impact Test Equipment and the results are as follows:

1) Area of the specimen under the test $=43.4964 \mathrm{sq} \cdot \mathrm{m}$

2) Energy absorbed by the specimen $=24 \mathrm{~J}$

3) Impact strength of the specimen $=0.55177 \mathrm{~J} / \mathrm{sq} \cdot \mathrm{mm}$
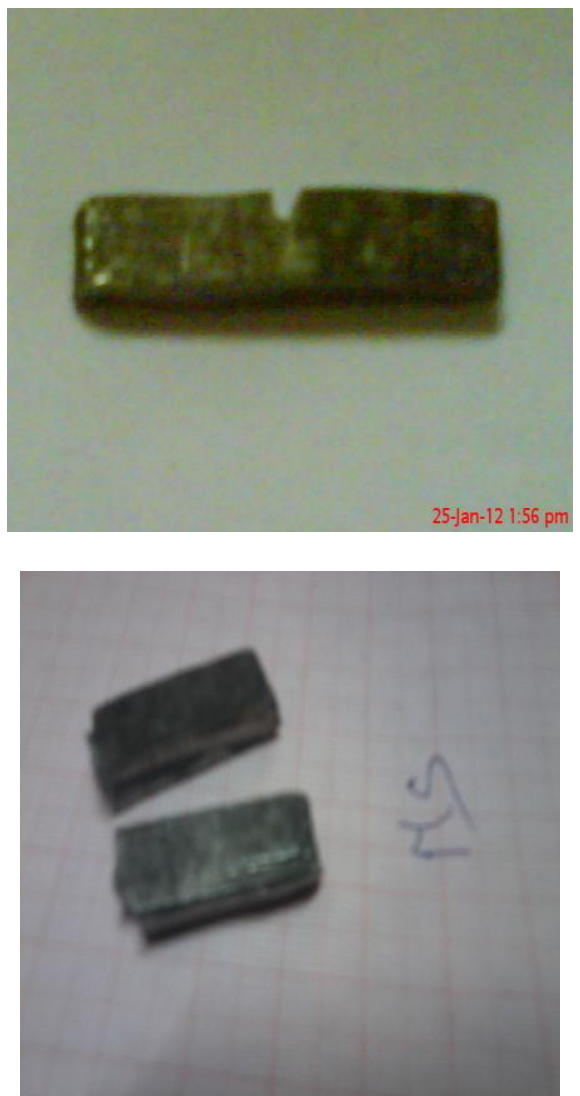

Fig 4.13 Specimen Before Test Specimen After Test

\subsection{Impact Strength of Stainless Steel}


Stainless Steel specimen having the dimensions of $5 \mathrm{~mm}$ thickness, $10 \mathrm{~mm}$ width and $50 \mathrm{~mm}$ length is tested fot Impact Strength in the Charpy's Impact Test Equipment and the results are as follows:

1) Area of the specimen under the test $=41.7094 \mathrm{~mm}^{2}$

2) Energy absorbed by the specimen $=112 \mathrm{~J}$

3) Impact strength of the specimen $=2.68525 \mathrm{~J} / \mathrm{sq} \cdot \mathrm{mm}$
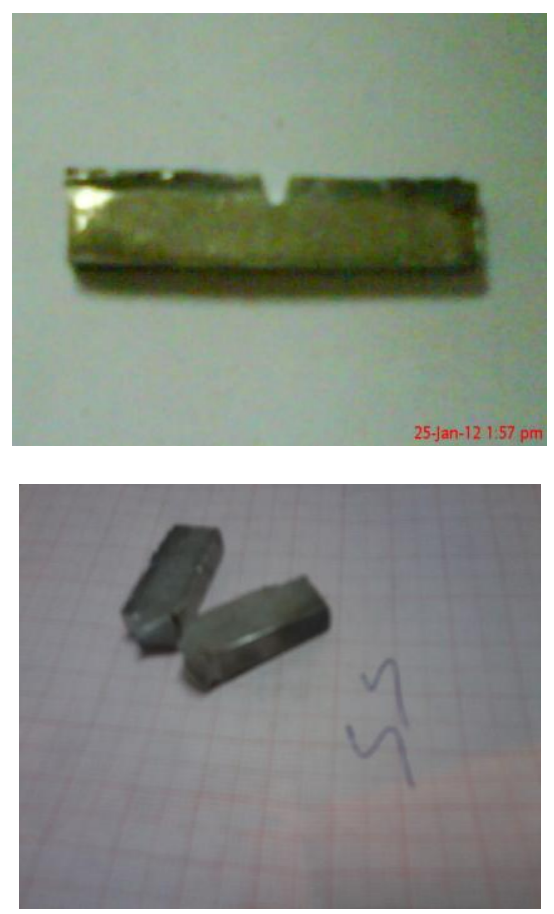

Fig 4.14 Specimen Before Test Specimen After Test

\subsection{Stainless Steel}

Elastic strength $=156000 \mathrm{~N}$

Ultimate strength $=258000 \mathrm{~N}$

\subsection{Mild Steel}

Elastic strength $=75000 \mathrm{~N}$

Ultimate Strength $=123000 \mathrm{~N}$

\section{CONCLUSION}

After performing the welding operation for Stainless Steel and Mild Steel having same thicknesses and different thicknesses, and carrying the Tensile Strength,Shear Strength tests over UTM and Impact Strength over Charpy's Impact Test Equipment the following results were concluded:

1) It is concluded that the Impact Strength of our considered specimen which is joined by using both TIG and ARC Welding's in Parallel and Perpendicular to the weld is more than the Mild Steel.

2) Impact strength of our considered specimen is approximately equal to the average to the Impact Strengths of Mild Steel and Stainless Steel, because the Stainless Steel is a ductile one.

3) Impact Strength of our considered specimen which is welded by ARC welding is more than the specimen which is welded by TIG Welding because an Extra fillet material is added during the welding operation at the weld zone.

4) Ultimate Strength of our considered specimen (having same thicknesses) which is welded by ARC welding is more than that of one which is welded by TIG welding because of filled material at the weld zone. Therefore we conclude that the ARC welding is more preferred.

5) Shear Strength of our considered specimen (having same thicknesses) which is welded by TIG welding is more than the specimen which is welded by ARC Welding. Therefore we conclude that TIG welding is more preferred for LAP Joints.

6) Ultimate Strength of our specimen Parallel to the direction of the application of load (having different thicknesses) which is welded by ARC welding is more than the specimen welded by TIG welding. Hence we conclude that the ARC welding is more preferred for welding specimens of different thicknesses.

7) Ultimate Strength of our specimen Perpendicular to the direction of the application of load (having different thicknesses) which is welded by ARC welding is more than the specimen welded by TIG welding. Hence we conclude that the ARC welding is more preferred for welding specimens of different thicknesses

\section{REFERENCES}

[1]. Vikram Viswanatham "Journal on Materials and Manufacturing , vol. 110, Section 5, pp673-679(2001) ", Northwestren University ,Evanston

[2]. V.R.Radha Krishnan, "Welding Technology and Design"

[3]. P.C.Sharma,"A Text Book of Production Technology",Chand Publications

[4]. M. Garware,ASM International Journal-2010.

[5]. Jian Cao, "Journal of Manufacturing Science and Engineering". Department of Mechanical Engineering, Northwest University,Evanaton

\section{BIOGRAPHIES}

The author T. Kishore kumar has completed his B.tech (mechanical) at G.Pulla Reddy engineering college in 2012 and his M.tech(product design) at JNTU ananthapuramu in 2014 and is working as asst prof of mechanical engg dept at Dr.K.V.S.R.I.T. his areas of interest are design and analysis of products.

The author K. Jayasimha reddy has completed his B.tech (mechanical) in 2012 and his M.tech (thermal sciences and energy systems) in 2014 at G.Pulla Reddy engineering college and is working as asst prof of mechanical engg dept at Dr.K.V.S.R.I.T. .his areas of interest are R\&AC, thermal energy storage, solar energy. 